\title{
Momentum Effect all over the World
}

Zulfiqar Ali Imran*

School of Economic, Finance \& Banking

Universiti Utara Malaysia, University of Lahore, Pakistan

Woei-Chyuan Wong

Rusmawati Ismail

School of Economics, Finance \& Banking, Universiti Utara Malaysia, Malaysia

*Corresponding author: zulfiqaraliimran05@gmail.com

A R T I C L E I N F O

Article history:

Received 28 August 2019

Revised 26 September 2019

Accepted 30 September 2019

Published 6 January 2020

Keywords:

Momentum effect, reversals, momentum investment strategies, existence and profitability of momentum effect, efficient market hypothesis.

JEL Code: G11, G12
A B S T R A C T

This study is intended to reaffirm the existence and profitability of momentum investment strategies in 40 countries around the world during the period 1996-2018. The contradictory findings of previous research on the existence and profitability of momentum strategies have raised a pertinent question on the validity of efficient market hypothesis. We documented the momentum effect in $90 \%$ of our sample countries of which $52.5 \%$ exhibited positive momentum effect while $37.5 \%$ exhibited negative momentum effect. The findings were robust to two distinct sub-period analyses. The clear rejection of efficient market hypotheses is valuable to momentum traders and stock market regulators.

\section{Introduction}

Finance literature carries substantial evidence on the existence and profitability of momentum returns since the seminal work of Jegadeesh and Titman (1993). Many studies have documented instances where stocks kept on outperforming (underperforming) for the next three to 12 months if they had outperformed (underperformed) during several previous months. Jegadeesh and Titman (1993) 
analyzed the American Stock Exchange (AMEX) and New York Stock Exchange (NYSE) using post 1940 stock data. They reported a significant monthly average momentum profit of $1.49 \%$ when adopting a zero-cost momentum strategy of buying past winners and selling past losers. Similar results have also been documented in prominent cross-country studies such as Rouwenhorst (1998) who found momentum returns across all European stock markets. Rouwenhorst (1999) noted that $85 \%$ and $15 \%$ of the sample countries exhibited positive and negative momentum returns, respectively. Likewise, Griffin, Ji and Martin (2003) reported that $80 \%(18 \%)$ of their sample countries exhibited positive (negative) momentum returns, whereas $2 \%$ of their sample countries exhibited no momentum returns.

Researchers have been critical of the applicability of efficient market hypothesis $(\mathrm{EMH})$ in conventional finance ever since the discovery of the momentum effect in finance literature. The mere existence of the momentum effect in stock returns has invalidated the notion of EMH and strengthened the view point of opponents of market efficiency. The presence of momentum effects implied that a stock's own past prices could be utilized to predict its future prices and could also lead investors to earn abnormal profits. This is contrary to EMH which articulates that investors cannot use information based on securities' own past prices to make an abnormal profit because stock future prices are random in nature and are not affected by previous events (Malkiel, 2003; Malkiel \& Fama, 1970). The question arises then as to what extent are our financial markets informationally efficient and whether asset pricing models are reliable. This is because conventional asset pricing models are developed based on the assumption of market rationality, where chances of achieving excess returns are remote. If investors can beat the market through acquiring excess returns then the validity of conventional asset pricing model is highly questionable (Chen 2017).

Despite the fact that many studies have investigated momentum effects in stock markets around the world, there is no consensus among researchers on the existence and profitability of the momentum effect especially in developing stock markets. This contradictory evidence makes momentum profitability highly questionable in the literature and has been the subject of many empirical studies.

Hameed and Yuanto (2002) and Chui, Titman and Wei (2000), for instance, did not find any momentum effect in Asian stock markets in their samples. On the other hand, Griffin, Ji and Martin (2004) and Chui, Titman, and Wei (2010) documented the existence and profitability of the momentum effect in some of the Asian stock markets. Kang, Liu and Ni (2002) established the presence of positive momentum effect in the China stock market. A more recent study in China by Li, Qiu and Wu (2010) however, found no momentum profit. The presence of the momentum effect proved by Griffin, Ji and Martin (2004) in the Turkish stock market was also controversial as it was later denied by Ornelas and Fernandes (2008). 
One may argue that emerging markets are subject to higher volatility and greater uncertainty which caused the momentum effect, but the momentum effect is not confined to emerging stock markets. There are some developed stock markets such as in Australia and Japan where the momentum effect is also subject to many contradictions. Chui, Titman and Wei (2010) and Hurn and Pavlov (2003) for instance detected strong momentum effect in Australia which was unsupported in a later study by Huynh et al. (2010). Similarly, findings by Hong, Lee and Swaminathan (2003) of the insignificant momentum effect in Japan contradicted findings by Griffin, Ji and Martin (2004) who perceived significant momentum effects in the Japanese stock market.

We are unaware of any comprehensive study, after Chui, Titman and Wei (2010) who examined and reaffirmed the profitability of the momentum effect around the world. The ongoing debate on market efficiency (Shiller 2003) and contradictory findings on the existence of the momentum effect served as motivation in the current study. Therefore the main objective of our study is to revisit the profitability of the momentum effect around the world to confirm whether stock markets are informationally efficient or not. This study also has implications for individual and institutional investors which adopted momentum investment strategies. Momentum based strategies are risky and are subject to huge losses. According to Barroso and Santa-Clara (2015), momentum strategies crash up to $-91.59 \%$ in just two months and $-73.42 \%$ in three months during the 1932 and 2009 financial crises, respectively. Such huge losses cannot be compensated through decades of momentum profits. Our study is important for policymakers to understand how far momentum effect prevails in stock markets and whether they should take a more proactive role in regulating the stock markets.

The remainder of this paper is organised as follows: Section 2 presents the literature review, Section 3 explains the data, Section 4 describes the methodology, Section 5 clarifies the empirical findings and Section 6 concludes the study.

\section{Related Literature}

Jegadeesh and Titman (1993) discovered short term momentum effect in the U.S. stock markets. They examined the U.S. stock market from 1965 to 1989 and documented momentum investment strategies which generated $1.49 \%$ average momentum profits per month. In other words, they found that winner stocks were outperforming loser stocks by $1.49 \%$ for the next three to 12 months. However, their study only focused on the U.S. stock markets and disregarded the European and Asian stock markets.

Subsequent studies on momentum returns confirmed the existence of momentum profits outside of the U.S. markets. Rouwenhorst (1998) for instance, analysed 12 European stock markets from 1978 to 1985 that included United Kingdom, Switzerland, Sweden, Spain, Norway, Netherlands, Italy, Germany, 
France, Denmark, Belgium and Austria. He documented the past six months of winner stocks which outperformed the past six months of loser stocks by $1 \%$ per month in all the 12 European markets. A later study by Rouwenhorst (1999) who studied 1,750 firms in 20 emerging stock markets consisting of Argentina, Brazil, Chile, Colombia, Greece, Indonesia, India, Jordan, Korea, Malaysia, Mexico, Nigeria, Pakistan, Philippines, Portugal, Taiwan, Thailand, Turkey, Venezuela and Zimbabwe found that 17 out of the 20 emerging stock markets exhibited momentum effect.

Although there is ample evidence on the existence and profitability of the momentum effect, there are also numerous studies that contradicted the profitability and existence of the momentum effect. Chui, Titman and Wei (2001) examined eight stock markets in Asia which included Hong Kong, Malaysia, Indonesia, Taiwan, Korea, Thailand, Japan and Singapore. They found positive momentum effect in Hong Kong, Malaysia, Singapore and Thailand but no momentum effect in Indonesia, Japan, Taiwan and Korea. This study, however, lacked generalizability as they only considered eight Asian countries.

The existence of the momentum effect was also opposed by Hameed and Yuanto (2002) who studied 1,000 firms in six Asian stock markets comprising of Hong Kong, Malaysia, Singapore, South Korea, Taiwan and Thailand. They applied Jegadeesh and Titman's (1993) momentum methodology and concluded that all 16 momentum strategies were consistently insignificant in the six Asian stock markets. Moreover, Hameed and Yuanto (2002) argued that the momentum effect was the result of data snooping bias. ${ }^{1}$ Ornelas and Fernandes (2008) also did not find evidence of momentum effect in Brazil, Indonesia, Australia, Pakistan, Poland, Romania and Turkey. They related their findings of insignificant momentum effects with the improvement in information technology and use of the Internet that helped channel information to investors with greater speed which in turn wiped out the momentum effect. If higher information technology and use of the Internet wiped out the momentum effect, then all else being equal, developed countries, should have a lower momentum effect as compared to developing countries. This contention was not supported by existing studies which found that developed countries exhibited higher momentum effect than their developing counterparts (Rouwenhorst 1999, 1998).

Although a substantial amount of literature on momentum effect favoured the existence and profitability of momentum strategies in many countries around the world, there are also many studies that contradicted these findings specifically in the context of emerging markets. The existence and profitability of the momentum effect in emerging markets is not unanimous in the literature. Moreover, there is no study examining momentum returns on a global scale after Chui, Titman and Wei (2010). Thus, it is important to reaffirm the existence of momentum effect around the world. Table 1 presents the list of countries, along with researchers who investigated the existence of momentum returns.

Data snooping refers to statistical inference which researchers decide to perform after looking at related data. 
Table 1. Countries and Momentum Returns

\begin{tabular}{|c|c|}
\hline \multicolumn{2}{|r|}{ Panel A. List of Countries with Significant Momentum Returns } \\
\hline Country & Author \\
\hline Argentina & $\begin{array}{l}\text { Rouwenhorst (1999); Chui, Titman and Wei (2010); Griffin, Ji and Martin } \\
\text { (2003) }\end{array}$ \\
\hline Africa & Griffin, Ji and Martin (2003) \\
\hline Australia & Griffin, Ji and Martin (2003) \\
\hline Austria & $\begin{array}{l}\text { Rouwenhorst (1998); Chui, Titman and Wei (2010); Griffin, Ji and Martin } \\
\text { (2003) }\end{array}$ \\
\hline Bangladesh & Chui, Titman and Wei (2010) \\
\hline Belgium & $\begin{array}{l}\text { Rouwenhorst (1998); Chui, Titman and Wei (2010); Griffin, Ji and Martin } \\
\text { (2003) }\end{array}$ \\
\hline Brazil & $\begin{array}{l}\text { Rouwenhorst (1999); Chui, Titman and Wei (2010); Griffin, Ji and Martin } \\
\text { (2003) }\end{array}$ \\
\hline Nigeria & Rouwenhorst (1999) \\
\hline Jordan & Rouwenhorst (1999) \\
\hline Korea & Rouwenhorst (1999) \\
\hline Malaysia & Rouwenhorst (1999); Griffin, Ji and Martin (2003) \\
\hline Mexico & Rouwenhorst (1999); Griffin, Ji and Martin (2003) \\
\hline Netherlands & $\begin{array}{l}\text { Rouwenhorst (1998); Chui, Titman and Wei (2010); Griffin, Ji and Martin } \\
\text { (2003) }\end{array}$ \\
\hline New Zealand & Griffin, Ji and Martin (2003) \\
\hline Norway & $\begin{array}{l}\text { Rouwenhorst (1998); Chui, Titman and Wei (2010); Griffin, Ji and Martin } \\
\text { (2003) }\end{array}$ \\
\hline Pakistan & $\begin{array}{l}\text { Rouwenhorst (1999); Chui, Titman and Wei (2010); Griffin, Ji and Martin } \\
\text { (2003) }\end{array}$ \\
\hline Peru & Griffin, Ji and Martin (2003) \\
\hline Philippines & $\begin{array}{l}\text { Rouwenhorst (1999); Chui, Titman and Wei (2010); Griffin, Ji and Martin } \\
\text { (2003) }\end{array}$ \\
\hline Poland & Chui, Titman and Wei (2010) \\
\hline Portugal & Rouwenhorst (1999); Griffin, Ji and Martin (2003) \\
\hline Singapore & Griffin, Ji and Martin (2003) \\
\hline South Africa & Griffin, Ji and Martin (2003) \\
\hline Spain & $\begin{array}{l}\text { Rouwenhorst (1998); Chui, Titman and Wei (2010); Griffin, Ji and Martin } \\
\text { (2003) }\end{array}$ \\
\hline
\end{tabular}


Panel A. List of Countries with Significant Momentum Returns

\begin{tabular}{|c|c|}
\hline Country & Author \\
\hline Sweden & $\begin{array}{l}\text { Rouwenhorst (1998); Chui, Titman and Wei (2010); Griffin, Ji and Martin } \\
\text { (2003) }\end{array}$ \\
\hline Taiwan & Rouwenhorst (1999); Griffin, Ji and Martin (2003) \\
\hline Thailand & Griffin, Ji and Martin (2003) \\
\hline Turkey & Rouwenhorst (1999); Griffin and Martin (2003) \\
\hline United Kingdom & $\begin{array}{l}\text { Rouwenhorst (1998); Chui, Titman and Wei (2010); Griffin, Ji and Martin } \\
(2003)\end{array}$ \\
\hline Venezuela & Rouwenhorst (1999) \\
\hline \multirow[t]{2}{*}{ Zimbabwe } & Rouwenhorst (1999) \\
\hline & Panel B. Countries with Controversial Momentum Returns \\
\hline Hong Kong & Hameed and Yuanto (2002) \\
\hline Switzerland & $\begin{array}{l}\text { Rouwenhorst (1998); Chui, Titman and Wei (2010); Griffin, Ji and Martin } \\
(2003)\end{array}$ \\
\hline Malaysia & Hameed and Yuanto (2002) \\
\hline Singapore & Hameed and Yuanto (2002) \\
\hline South Korea & Hameed and Yuanto (2002); Chui, Titman and Wei (2000) \\
\hline Taiwan & Hameed and Yuanto (2002) \\
\hline Thailand & Hameed and Yuanto (2002) \\
\hline Japan & Chui, Titman and Wei (2000); Teplova and Mikova (2015) \\
\hline Indonesia & Fernandes and Ornelas (2008); Chui, Titman and Wei (2000) \\
\hline Australia & Henker, Henker and Huynh (2010) \\
\hline Brazil & Fernandes and Ornelas (2008) \\
\hline Pakistan & Fernandes and Ornelas (2008) \\
\hline Poland & Fernandes and Ornelas (2008) \\
\hline Romania & Fernandes and Ornelas (2008) \\
\hline Turkey & Fernandes and Ornelas (2008) \\
\hline
\end{tabular}

\section{Data}

The stock price data used to compute momentum returns was obtained from DataStream. The final sample consisted of 40 countries with complete stock 
price data from 1996 to 2018 . The initial sample consisted of 40,365 firms from the 40 countries but after the screening process, 9,332 firms were left. During the screening process, firms with incomplete monthly return values from 1996 to 2018 were dropped. Table 2 provides the list of countries included in our study along with the total number of firms.

Table 2. Total Numbers of Firms

\begin{tabular}{|c|c|c|c|}
\hline No. & Country & Total Number of Firms & Number of Firms Retained \\
\hline 1 & Bangladesh & 348 & 97 \\
\hline 2 & Brazil & 610 & 156 \\
\hline 3 & China & 3706 & 366 \\
\hline 4 & Colombia & 99 & 28 \\
\hline 5 & India & 4860 & 1791 \\
\hline 6 & Indonesia & 629 & 171 \\
\hline 7 & Kenya & 69 & 39 \\
\hline 8 & Malaysia & 965 & 303 \\
\hline 9 & Morocco & 75 & 17 \\
\hline 10 & Pakistan & 365 & 158 \\
\hline 11 & Philippines & 312 & 159 \\
\hline 12 & South Africa & 399 & 112 \\
\hline 13 & Sri Lanka & 301 & 163 \\
\hline 14 & Thailand & 1242 & 413 \\
\hline 15 & Turkey & 394 & 142 \\
\hline 16 & Australia & 2172 & 380 \\
\hline 17 & Belgium & 154 & 46 \\
\hline 18 & Canada & 3684 & 760 \\
\hline 19 & Chile & 211 & 110 \\
\hline 20 & Denmark & 162 & 86 \\
\hline 21 & Finland & 172 & 52 \\
\hline 22 & France & 860 & 236 \\
\hline 23 & Germany & 876 & 231 \\
\hline 24 & Greece & 194 & 74 \\
\hline 25 & Hong Kong & 3336 & 453 \\
\hline 26 & Israel & 414 & 190 \\
\hline 27 & Italy & 462 & 72 \\
\hline 28 & Japan & 1174 & 481 \\
\hline 29 & Korea & 2378 & 473 \\
\hline
\end{tabular}




\begin{tabular}{llcc}
\hline No. & Country & Total Number of Firms & Number of Firms Retained \\
\hline 30 & Netherlands & 130 & 60 \\
31 & New Zealand & 150 & 38 \\
32 & Norway & 299 & 42 \\
33 & Poland & 820 & 21 \\
34 & Singapore & 522 & 113 \\
35 & Spain & 275 & 51 \\
36 & Sweden & 917 & 99 \\
37 & Switzerland & 283 & 123 \\
38 & Taiwan & 1970 & 284 \\
39 & United Kingdom & 1507 & 373 \\
40 & United States & 2869 & 369 \\
\hline Total Number of Firms & 40,365 & 9,332 \\
\hline
\end{tabular}

Source: Author's own calculations.

\section{Methodology}

This study adopted the momentum strategy J6K6 developed by Jegadeesh and Titman (1993). Their strategy stands as a benchmark to calculate momentum returns and has been used by subsequent researchers such as Chui, Titman, and Wei (2010), Griffin, Ji, and Martin (2003), Ji, Martin, and Yao (2017), and Rouwenhorst (1998). Stock returns are calculated through the following formula.

$$
\text { Returns }=\left(\frac{P_{t}-P_{t-1}}{P_{t-1}}\right) * 100
$$

Where $\mathrm{P}_{t}$ is a closing price in month $\mathrm{t}$ and $\mathrm{P}_{\mathrm{t}-1}$ is an opening price in month $\mathrm{t}-1$. Next, stocks are ranked in ascending order based on their cumulative returns at the end of each month for the past six months. The top $10 \%$ of the stocks are classified as winner portfolios while the bottom $10 \%$ are loser portfolios. These winner and loser portfolios are held for the next six months. This strategy is known as J6K6 in the literature where J6 refers to the six months formation period while K6 refers to the six months holding period. For example, a J6K6 portfolio on $1^{\text {st }}$ July 2016 will show the performance of a portfolio from 31 December 2015 to 30 June 2016 (J6) and will be held until 31 December 2016 (K6). To calculate winner minus loser portfolio, the average loser portfolio returns are deducted from the average winner portfolio returns. The average value of winner minus loser portfolio is the momentum return where t-statistics is used to measure the significance level of the momentum returns. 


\section{Empirical Findings}

This section discusses the momentum profitability in 40 countries around the world from 1996 to 2018 . Table 3 shows the monthly average momentum returns for each of these countries along with their respective t-statistics. For robustness sake, the momentum results during the sub-periods of 1997 to 2006 and 2007 to 2018 are also reproduced. Table 3 groups the sample countries according to their respective momentum returns (full sample) whether they are positive and significant (Panel A), negative and significant (Panel B) or insignificant (Panel C). Panel D tabulates the average momentum returns of all countries according to full and sub-periods.

As shown in Table 3, 21 and 15 countries exhibited positive and significant, and negative and significant momentum returns, respectively, during the full sample period. These findings were robust to the two sub-period analyses. The exceptions were Thailand, Netherlands, Israel, US and Italy where the momentum returns either turned insignificant or flipped during the subperiod analysis. Netherlands for instance had positive and significant momentum returns in the full sample period but turned insignificant during first sub-period (1996-2006). The U.S. and Italy experienced positive and significant momentum returns in the full sample period but turned negative and significant in the first sub sample period.

Momentum returns were insignificant in Taiwan, Colombia, Spain and Greece for the full sample period as shown in Panel C of Table 3. Panel D shows the average momentum return of all countries. The average momentum returns were $0.25 \%, 0.18 \%$ and $0.24 \%$ during the full sample, first and second subperiods, respectively.

Table 3. Country Wise Average Monthly Momentum Returns (\%)

\begin{tabular}{|c|c|c|c|}
\hline S. No & Country & $\begin{array}{c}\text { Average Monthly Momentum } \\
\text { Profits (\%) }\end{array}$ & T-Stat \\
\hline \multicolumn{4}{|c|}{ Panel A: Positive Monthly Momentum Returns } \\
\hline 1 & Bangladesh & & \\
\hline & Full Sample (1996-2018) & $1.81^{* * *}$ & 21.75 \\
\hline & First Sub-Sample (1996-2006) & $1.99 * * *$ & 16.65 \\
\hline & Second Sub-Sample (2007-2018) & $1.65^{* * *}$ & 25.99 \\
\hline \multirow[t]{4}{*}{2} & China & & \\
\hline & Full Sample (1996-2018) & $1.72 * * *$ & 52.09 \\
\hline & First Sub-Sample (1996-2006) & $2.25 * * *$ & 58.10 \\
\hline & Second Sub-Sample (2007-2018) & $1.28 * * *$ & 47.08 \\
\hline
\end{tabular}




\begin{tabular}{|c|c|c|c|}
\hline S. No & Country & $\begin{array}{c}\text { Average Monthly Momentum } \\
\text { Profits (\%) }\end{array}$ & T-Stat \\
\hline
\end{tabular}

Panel A: Positive Monthly Momentum Returns

3 Kenya

Full Sample (1996-2018)

First Sub-Sample (1996-2006)

Second Sub-Sample (2007-2018)

4 Morocco

Full Sample (1996-2018)

First Sub-Sample (1996-2006)

Second Sub-Sample (2007-2018)

5 South Africa

Full Sample (1996-2018)

First Sub-Sample (1996-2006)

Second Sub-Sample (2007-2018)

6 Thailand

Full Sample (1996-2018)

First Sub-Sample (1996-2006)

Second Sub-Sample (2007-2018)

7 Belgium

Full Sample (1996-2018)

First Sub-Sample (1996-2006)

Second Sub-Sample (2007-2018)

8 Chile
$0.47 * * *$

4.25

$0.56^{* * *}$

4.50

$0.41 * * *$

4.05

$0.98 * * *$

5.42

$1.29^{* * *}$

6.61

$0.67 * * *$

4.22

$1.56^{* * *}$

22.56

$2.14 * * *$

27.44

$0.97 * * *$

17.22

$0.12^{* * *} \quad 5.51$

$0.25^{* * *}$

10.48

0.01

$\begin{array}{rll}\text { Full Sample (1996-2018) } & 0.82 * * * & 24.19 \\ \text { First Sub-Sample (1996-2006) } & 0.64 * * * & 14.25 \\ \text { Second Sub-Sample (2007-2018) } & 0.97 * * * & 32.47\end{array}$

Level of significance, ${ }^{*} \mathrm{p}<0.01,{ }^{* *} \mathrm{p}<0.05,{ }^{* * *} \mathrm{p}<0.1$ 
Table 3 (Continued)

\begin{tabular}{|c|c|c|c|}
\hline S. No & Country & $\begin{array}{c}\text { Average Monthly Momentum } \\
\text { Profits (\%) }\end{array}$ & T-Stat \\
\hline \multirow[t]{4}{*}{9} & Denmark & & \\
\hline & Full Sample (1996-2018) & $1.24 * * *$ & 22.29 \\
\hline & First Sub-Sample (1996-2006) & $1.2^{* * *}$ & 19.31 \\
\hline & Second Sub-Sample (2007-2018) & $1.28 * * *$ & 24.79 \\
\hline \multirow[t]{4}{*}{10} & Finland & & \\
\hline & Full Sample (1996-2018) & $3.20 * * *$ & 27.05 \\
\hline & First Sub-Sample (1996-2006) & $3.9^{* * *}$ & 25.54 \\
\hline & Second Sub-Sample (2007-2018) & $2.62 * * *$ & 28.30 \\
\hline \multirow[t]{4}{*}{11} & Germany & & \\
\hline & Full Sample (1996-2018) & $2.04 * * *$ & 72.20 \\
\hline & First Sub-Sample (1996-2006) & $2.63^{* * *}$ & 73.32 \\
\hline & Second Sub-Sample (2007-2018) & $1.55^{* * *}$ & 71.27 \\
\hline \multirow[t]{4}{*}{12} & Italy & & \\
\hline & Full Sample (1996-2018) & $0.24 * * *$ & 5.45 \\
\hline & First Sub-Sample (1996-2006) & $-0.9 * * *$ & -5.62 \\
\hline & Second Sub-Sample (2007-2018) & $1.18^{* * *}$ & 14.66 \\
\hline \multirow[t]{4}{*}{13} & Netherlands & & \\
\hline & Full Sample (1996-2018) & $0.41 * * *$ & 5.20 \\
\hline & First Sub-Sample (1996-2006) & -0.35 & -0.64 \\
\hline & Second Sub-Sample (2007-2018) & $1.03 * * *$ & 10.06 \\
\hline \multirow[t]{4}{*}{14} & New Zealand & & \\
\hline & Full Sample (1996-2018) & $1.44 * * *$ & 11.15 \\
\hline & First Sub-Sample (1996-2006) & $1.97^{* * *}$ & 10.91 \\
\hline & Second Sub-Sample (2007-2018) & $1.01 * * *$ & 11.35 \\
\hline \multirow[t]{4}{*}{15} & Norway & & \\
\hline & Full Sample (1996-2018) & $2.76^{* * *}$ & 21.24 \\
\hline & First Sub-Sample (1996-2006) & $3.49^{* * *}$ & 22.99 \\
\hline & Second Sub-Sample (2007-2018) & $2.14 * * *$ & 19.78 \\
\hline \multirow[t]{4}{*}{16} & Poland & & \\
\hline & Full Sample (1996-2018) & $1.53^{* * *}$ & 6.86 \\
\hline & First Sub-Sample (1996-2006) & $2.14 * * *$ & 9.59 \\
\hline & Second Sub-Sample (2007-2018) & $1.03 * * *$ & 4.60 \\
\hline
\end{tabular}




\section{Table 3 (Continued)}

17 Singapore

Full Sample (1996-2018)

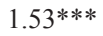

6.85

First Sub-Sample (1996-2006)

$2.14 * * *$

9.56

Second Sub-Sample (2007-2018)

$1.03 * * *$

4.59

18 Sweden

Full Sample (1996-2018)

$3.69 * * *$

51.16

First Sub-Sample (1996-2006)

$4.66 * * *$

46.57

Second Sub-Sample (2007-2018)

$2.87 * * *$

54.98

Level of significance, ${ }^{*} \mathrm{p}<0.01,{ }^{* *} \mathrm{p}<0.05,{ }^{* * *} \mathrm{p}<0.1$

\begin{tabular}{|c|c|c|c|}
\hline S. No & Country & $\begin{array}{c}\text { Average Monthly } \\
\text { Momentum Profits (\%) }\end{array}$ & T-Stat \\
\hline \multirow[t]{4}{*}{19} & Switzerland & & \\
\hline & Full Sample (1996-2018) & $2.84 * * *$ & 57.90 \\
\hline & First Sub-Sample (1996-2006) & $3.50 * * *$ & 63.78 \\
\hline & Second Sub-Sample (2007-2018) & $2.28 * * *$ & 53.00 \\
\hline \multirow[t]{4}{*}{20} & United Kingdom & & \\
\hline & Full Sample (1996-2018) & $1.46^{* * *}$ & 96.10 \\
\hline & First Sub-Sample (1996-2006) & $1.90 * * *$ & 102.71 \\
\hline & Second Sub-Sample (2007-2018) & $1.10 * * *$ & 90.58 \\
\hline \multirow[t]{4}{*}{21} & United States & & \\
\hline & Full Sample (1996-2018) & $0.17 * * *$ & 8.04 \\
\hline & First Sub-Sample (1996-2006) & $-0.14 * *$ & -2.07 \\
\hline & Second Sub-Sample (2007-2018) & $0.43 * * *$ & 16.46 \\
\hline
\end{tabular}

Panel B: Negative Monthly Momentum Returns

22 Brazil

$\begin{array}{rcc}\text { Full Sample (1996-2018) } & -0.89 * * * & -22.07 \\ \text { First Sub-Sample (1996-2006) } & -1.19 * * * & -21.30 \\ \text { Second Sub-Sample (2007-2018) } & -0.46 * * * & -22.72\end{array}$

23 India

$\begin{array}{rrr}\text { Full Sample (1996-2018) } & -2.34 * * * & -28.62 \\ \text { First Sub-Sample (1996-2006) } & -3.20 * * * & -30.02 \\ \text { Second Sub-Sample (2007-2018) } & -1.54 * * * & -27.00\end{array}$

24 Indonesia

Full Sample (1996-2018)

$-6.23 * * *$

$-52.64$ 


\begin{tabular}{|c|c|c|c|}
\hline \multicolumn{4}{|c|}{ Table 3 (Continued) } \\
\hline S. No & Country & $\begin{array}{c}\text { Average Monthly } \\
\text { Momentum Profits (\%) }\end{array}$ & T-Stat \\
\hline & First Sub-Sample (1996-2006) & $-10.72 * * *$ & -37.06 \\
\hline & Second Sub-Sample (2007-2018) & $-2.50 * * *$ & -65.63 \\
\hline \multirow[t]{4}{*}{25} & Malaysia & & \\
\hline & Full Sample (1996-2018) & $-2.32 * * *$ & -45.40 \\
\hline & First Sub-Sample (1996-2006) & $-3.35 * * *$ & -33.70 \\
\hline & Second Sub-Sample (2007-2018) & $-1.463 * * *$ & -55.15 \\
\hline \multirow[t]{4}{*}{26} & Pakistan & & \\
\hline & Full Sample (1996-2018) & $-1.08 * * *$ & -18.85 \\
\hline & First Sub-Sample (1996-2006) & $-2.19 * * *$ & -36.78 \\
\hline & Second Sub-Sample (2007-2018) & $-0.15 * * *$ & -3.91 \\
\hline
\end{tabular}

Level of significance, ${ }^{*} \mathrm{p}<0.01,{ }^{* *} \mathrm{p}<0.05,{ }^{* * *} \mathrm{p}<0.1$

$27 \quad$ Philippines

Full Sample (1996-2018)

First Sub-Sample (1996-2006)

Second Sub-Sample (2007-2018)

28 Sri Lanka

Full Sample (1996-2018)

First Sub-Sample (1996-2006)

Second Sub-Sample (2007-2018)

29 Turkey

Full Sample (1996-2018)

First Sub-Sample (1996-2006)

Second Sub-Sample (2007-2018)

$30 \quad$ Australia

Full Sample (1996-2018)

First Sub-Sample (1996-2006)

Second Sub-Sample (2007-2018)

31 Canada

\section{$-2.19 * * *$}

$-23.03$

$-0.95 * * *$

$-13.95$

$-3.23 * * *$

$-30.60$
$-1.13 * * * \quad-20.41$

$-2.12 * * *$

$-36.43$

$-0.29 * * *$

$-7.07$

$-1.98 * * *$

$-33.22$

$-2.31 * * *$

$-34.68$

$-1.71 * * *$

$-32.00$

$\begin{array}{ll}-0.38 * * * & -10.15 \\ -0.81 * * * & -19.25 \\ -0.03 * * * & -2.58\end{array}$

$\begin{array}{cc}-1.62 * * * & -10.68 \\ -1.54 * * * & -21.58 \\ -1.68 & -1.59\end{array}$




\section{Table 3 (Continued)}

\begin{tabular}{|c|c|c|c|}
\hline S. No & Country & $\begin{array}{c}\text { Average Monthly } \\
\text { Momentum Profits (\%) }\end{array}$ & T-Stat \\
\hline \multirow[t]{4}{*}{32} & France & & \\
\hline & Full Sample (1996-2018) & $-0.39 * * *$ & -11.22 \\
\hline & First Sub-Sample (1996-2006) & $-0.16^{* * *}$ & -5.03 \\
\hline & Second Sub-Sample (2007-2018) & $-0.59 * * *$ & -16.38 \\
\hline \multirow[t]{4}{*}{33} & Hong Kong & & \\
\hline & Full Sample (1996-2018) & $-0.59 * * *$ & -29.76 \\
\hline & First Sub-Sample (1996-2006) & $-0.52 * * *$ & -22.14 \\
\hline & Second Sub-Sample (2007-2018) & $-0.66 * * *$ & -34.94 \\
\hline \multirow[t]{4}{*}{34} & Israel & & \\
\hline & Full Sample (1996-2018) & $-0.33 * * *$ & -5.69 \\
\hline & First Sub-Sample (1996-2006) & $-0.73 * * *$ & -12.76 \\
\hline & Second Sub-Sample (2007-2018) & 0.01 & 0.21 \\
\hline
\end{tabular}

Level of significance, ${ }^{*} \mathrm{p}<0.01, * * \mathrm{p}<0.05, * * * \mathrm{p}<0.1$

35 Japan

Full Sample (1996-2018)

First Sub Sample (1996-2006)

Second Sub Sample (2007-2018)

$36 \quad$ Korea

$\begin{array}{ll}-0.34 * * * & -32.85 \\ -0.15 * * * & -18.92 \\ -0.49 * * * & -44.92\end{array}$

$-0.36 * * *$

$-12.18$

First Sub-Sample (1996-2006)

$-0.44 * * *$

$-9.77$

Second Sub-Sample (2007-2018)

$-0.29 * * *$

Panel C: No Momentum Returns Based on Full Sample Period

$37 \quad$ Greece

$\begin{array}{rcc}\text { Full Sample (1996-2018) } & -0.42 & -0.23 \\ \text { First Sub-Sample (1996-2006) } & -0.98 & -1.99 \\ \text { Second Sub-Sample (2007-2018) } & 0.06 & 1.23\end{array}$

38 Taiwan

Full Sample (1996-2018)

0.05

$-1.35$

First Sub-Sample (1996-2006)

$0.74 * * *$

14.03

Second Sub-Sample (2007-2018)

$-0.52 * * *$ $-14.17$ 
Table 3 (Continued)

\begin{tabular}{|c|c|c|c|}
\hline S. No & Country & $\begin{array}{l}\text { Average Monthly Momen- } \\
\text { tum Profits }(\%)\end{array}$ & T-Stat \\
\hline \multirow[t]{4}{*}{39} & Colombia & & \\
\hline & Full Sample (1996-2018) & 0.08 & 1.15 \\
\hline & First Sub-Sample (1996-2006) & $0.34 * * *$ & 3.33 \\
\hline & Second Sub-Sample (2007-2018) & -0.14 & -0.67 \\
\hline \multirow[t]{4}{*}{40} & Spain & & \\
\hline & Full Sample (1996-2018) & -0.08 & -0.48 \\
\hline & First Sub-Sample (1996-2006) & 0.21 & -0.17 \\
\hline & Second Sub-Sample (2007-2018) & -0.32 & -0.74 \\
\hline
\end{tabular}

Panel D: Overall Average Monthly Momentum Returns in 40 Countries

All Countries

Full Sample (1996-2018)

$0.25^{* * *} \quad 4.86$

First Sub-Sample (1996-2006) $\quad 0.18 * * * \quad 4.78$

Second Sub-Sample (2007-2018)

$0.24 * * *$

4.93

Level of significance, ${ }^{*} \mathrm{p}<0.01,{ }^{* *} \mathrm{p}<0.05, * * * \mathrm{p}<0.1$

Table 4 compares findings of the current study with five main international studies on momentum returns. Rouwenhorst (1999) found that the J6K6 momentum strategy produced $0.39 \%$ monthly average momentum returns in Asian stock markets where $85 \%$ and $15 \%$ of the sample countries exhibited positive and negative significant momentum returns, respectively. Hameed and Yuanto (2002) examined 16 momentum strategies in six Asian stock markets and observed that none of the sample countries were generating momentum returns. Griffin et al. (2003) studied momentum effects in 39 countries around the world. They discovered that the J6K6 investment strategy produced $0.49 \%$ monthly average momentum returns across the countries in their sample. A total of $80 \%$ and $18 \%$ of the countries had positive and negative momentum returns, respectively. Whereas, $2 \%$ of the sample countries did not exhibit momentum returns. Fernandes and Ornelas (2008) found positive momentum returns and negative momentum returns in $20 \%$ and $80 \%$ of their sample countries, respectively. Chui et al. (2010) examined momentum returns across 40 countries and perceived that $62.5 \%$ of their sample countries showed insignificant momentum returns. Meanwhile, momentum returns were positive (negative) in $52.5 \%(10 \%)$ of the sample countries. The overall monthly average momentum returns were $0.73 \%$ across 40 countries. The findings of the current study were also in line with the five international studies mentioned. We studied 40 countries across the world and found $0.25 \%$ monthly average momentum returns. 


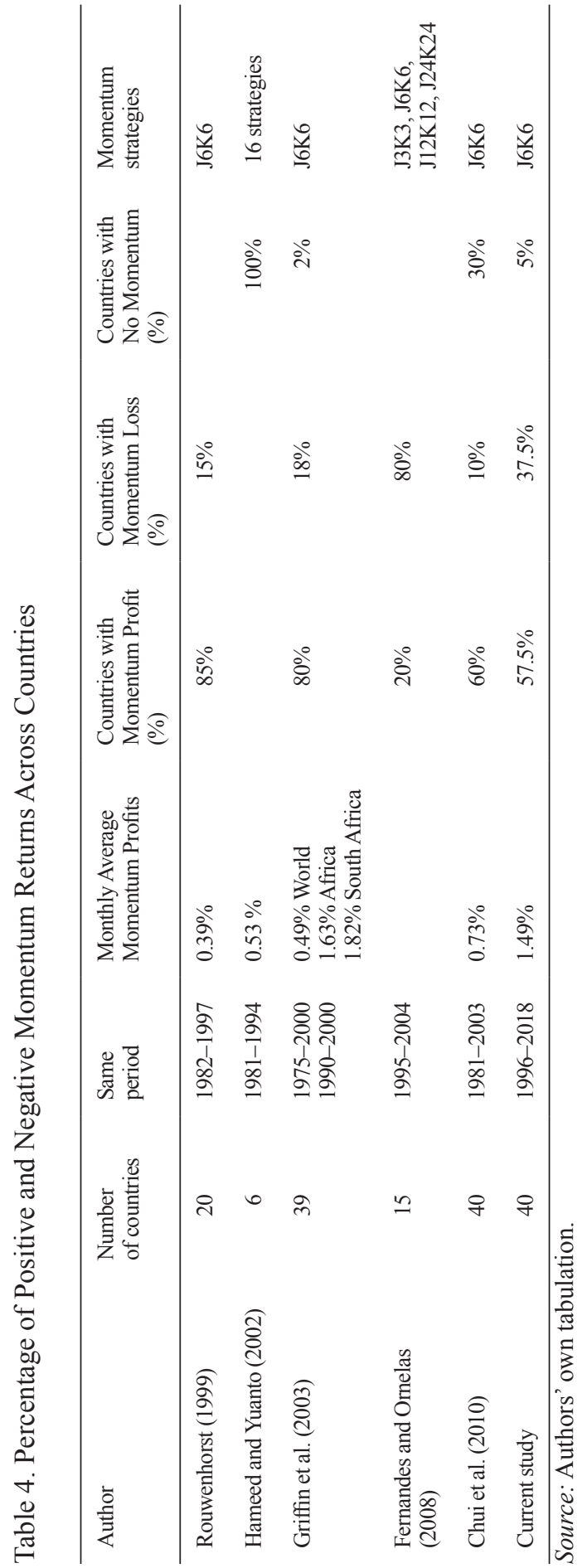


Our findings confirmed the existence of the momentum effect in 36 (90\%) countries out of 40 countries where $52.5 \%$ of the countries had positive and significant momentum returns and $37.5 \%$ of the countries had negative and significant momentum returns. A total of $10 \%$ of the sample countries had insignificant momentum returns for the full sample period. One noteworthy difference between our study and studies by Rouwenhorst (1998, 1999), Hameed and Yuanto (2002) and Chui et al. (2010) was the existence of a significant number of countries with negative momentum returns which implied the existence of return reversals, i.e. past losers outperformed past winners and vice versa. The significant number of countries with negative momentum returns was however consistent with Fernandes and Ornelas (2008) who obtained reversals in 10 out of 15 emerging stock markets.

As suggested by De Bondt and Thaler (1985, 1987), contrarian investment strategies of buying past loser stocks and selling past winner stocks could produce abnormal profits due to the overreaction of investors. Both return momentum and reversals invalidated the notion of efficient market hypothesis. Jegadeesh and Titman (1993) also showed that return reversals could take place after 12 months.

Another possible reason why our results were different from previous studies was because of the sample selection criteria. Rouwenhorst (1999) excluded $5 \%$ of the stocks based on their extreme past performance during the ranking (formation) period. Moreover, Rouwenhorst (1999) used the 30\% cutoff point in determining winner and loser stocks. Whereas, we applied a $10 \%$ cut-off and did not apply any data filtering technique except deleting stocks that did not have values to full length.

\section{Conclusion}

This study revisited the existence and profitability of momentum returns on a global scale. This is necessary since 16 years have passed since the study by Chui et al. (2010) with a sample period which ended in 2003. It is important to identify the magnitude of momentum returns across countries so that policymakers are aware of the validity of EMH in their respective stock markets. Our findings offered a clear rejection of the notion of EMH as $90 \%$ of the sample countries exhibited significant momentum returns.

Our study has implications for practitioners and policymakers. The main findings of the current study offer guidance to individual investors, investment houses and institutional investors as to which country(s) the J6K6 momentum investment strategies tend to be profitable. On the other hand, investors should also be aware of the losses associated with momentum strategies as supported by our findings on return reversals in $37.5 \%$ of our sample countries. In addition, investors should implement momentum strategies with caution due to the rapid speed of information diffusion in stock prices in recent years. This could 
eradicate momentum profits a lot sooner than what investors have predicted. Policymakers should take into consideration the behavioural aspects of investors when designing regulations to curb excessive volatility in the market. They need to identify investor psychological biases that cause stock prices to deviate from their fundamental values for a prolonged period.

Further research can be conducted to identify the determinants of momentum profits and losses by analysing risk factors such as liquidity and book-to-market value. Moreover, the effect of information technology and speed of information diffusion can also be explored to find out the source(s) of momentum effect.

\section{References}

Barroso, P., \& Santa-Clara, P. (2015). Momentum has its moments. Journal of Financial Economics, 116(1), 111-120.

De Bondt, W. F. M., \& Thaler, R. (1985). Does the stock market overreact? The Journal of Finance, 40(3), 793-805.

Fernandes, J. L. B., \& Ornelas, J. R. H. (2008). Momentum and reversal puzzle in emerging markets. Journal of Behavioral Finance, 5(3), 54-71.

Chui, A. C. W., Titman, S., \& Wei, K. C. J. (2000). Momentum, legal systems and ownership structure-an analysis of Asian stock markets. SSRN Electronic Journal.

Chui, A. C. W., Titman, S., \& Wei, K. C. J. (2010). Individualism and momentum around the world. Journal of Finance, 65(1), 361-392.

Daniel, K., Hirshleifer, D., \& Subrahmanyam, A. (1998). Investor psychology and security market under-and overreactions. The Journal of Finance, 53(6), 1839-1885.

Fernandes, J. L. B., \& Ornelas, J. R. H. (2008). Momentum and reversal puzzle in emerging markets. Journal of Behavioral Finance, 5(3), 54-71.

Griffin, J. M., Ji, S., \& Martin, J. S. (2004). Global momentum strategies: A portfolio perspective. The Journal of Portfolio Management, 31(2), 2339.

Griffin, J. M., Ji, X., \& Martin, J. S. (2003). Momentum investing and business cycle risk: Evidence from pole to pole. The Journal of Finance, 58(6), 2515-2547.

Hameed, A., \& Yuanto, K. (2002). Momentum strategies : Evidence from the pacific basin stock markets. Journal of Financial Research, XXV(3), 383-397.

Hong, D., Lee, C. M. C., \& Swaminathan, B. (2003). Earnings momentum in international markets. SSRN Electronic Journal, (February). https://doi. org/10.2139/ssrn.390107

Hurn, S., \& Pavlov, V. (2003). Momentum in Australian stock returns. Australian Journal of Management, 28(2), 141-155. 
Huynh, T. D., Henker, T., \& Henker, J. (2010). Survivorship bias and alternative explanations of momentum effect. SSRN Electronic Journal.

Jegadeesh, N., \& Titman, S. (1993). American finance association returns to buying winners and selling losers: Implications for stock market efficiency author (s): Narasimhan Jegadeesh and Sheridan Titman Source : The Journal of Finance, Vol . 48 , No . 1 (Mar., 1993), pp . 6591 Pub. The Journal of Finance, 48(1), 65-91.

Kang, J., Liu, M.-H., \& Ni, S. X. (2002). Contrarian and momentum strategies in the China stock market: 1993-2000. Pacific-Basin Finance Journal, 10(3), 243-265.

Li, B., Qiu, J., \& Wu, Y. (2010). Momentum and seasonality in Chinese stock markets. Journal of Money, Investment and Banking, 2010(17), 24-36.

Malkiel, B. G. (2003). The efficient market hypothesis and its critics. Journal of Economic Perspectives, 17(1), 59-82.

Malkiel, B. G., \& Fama, E. F. (1970). Efficient capital markets: A review of the theory. The Journal of Finance, 25(2), 383-417.

Rouwenhorst, K. G. (1998). International momentum strategies. The Journal of Finance, 53(1), 267-284.

Rouwenhorst, K. G. (1999). Local return factors and turnover in emerging stock markets. Journal of Finance, 54(4), 1439-1464.

Zhang, X. F. (2006). Information uncertainty and stock returns. Journal of Finance, 61(1), 105-137. 